\title{
AVRUPA TOPLULUĞU'nda FİKRİ-SINAİ MÜLKİYET HAKLARI ve SON GELIŞMELER*
}

\author{
Ayşe Saadet ARIKAN***
}

\section{Özet}

Fikrî ve sınaî miilkiyet haklarmın (FSH) korınmasının arkasında yatan neden, yaratıcının, yatırımcının ve toplumın yartşan çıkarları arasında bir denge sağlamaktır. Bu denge; yaratıcılara ödül olarak inhisarî yetkiler tanınarak, toplum lehine bu yatkilere istisnalar getirilerek ve ayn zamanda topluma, süreleri stmirlanmıs da olsa, bu inhisarî yetkilere saygı gösterme yükümlülïğ̈̈ getirilmek suretiyle sağlanmaktadır.

Devletler yukarda sözii edilen yaklaşım çerçevesinde FSHnın kontnmasın herzaman teknolojik ve kültïrel gelişmelerinin bir aracı olarak görmïşler ve koumayı ïlkesel sinırlar içerisinde bahşetmişlerdir. Bu ïlkesellik yaklaşımı nedeniyle bu hakların kapsamı, süresi, inhisarîliği bakımından farklı ulusal kurallar var olmuş ve bu hussus .FSHnun en çarpıcı özelliği olmuştur. FSH komusunda uhusal kuralların yeknesaklasstırılmadı̆̆ bir Avmupa Topluluğunda (AT) farklılıkların mevcudiyeti bu haklara konu olan malların serbest dolaşım açısından, hiç kuş̧kusuz bïyïk bir tehlike oluşturacak niteliktedir.

Bu makale ATnin, malların serbest dolaşımı, rekabet hukuku ilkeleri gibi hayati kurallar ile FSHnn ïlkesellik, inhisarîlik ilkelerinin gerek Kurucu Antlaşma hïkümleri, gerek Divan kararları aracılığı ile nasıl bağdaşır hale getirildiği somusuna hir cevap niteliğini taşımaktadır.

\footnotetext{
* Bu makale yazarın , 1998 yılından bu yana ATAUM' da ve 2002 yılından itibaren A.Ü Hukuk Fakültesi Jean Monnet Sertifika programında verdiği dersler esas alınarak hazırlanmış ve Lizbon Andlaşması dahil son gelişmelerin ışığı altında 18.3.2008 tarihinde gïncellenmiştir.

*** Yrd. Doç.Dr., Koç Üniversitesi Hukuk Fakültesi Öğretim Üyesi.
} 
Anahtar Kelimeler: Fikrî ve sinaî mülkiyet haklart, Avrupa Topluluğu, eser ïzerindeki haklar, bağlantıl haklar, patentler, faydalı modeller, endïstriyel tasarımlar, markalar, coğrafï işaretler, yariletken çip topografyaları, ıslahç̧ hakları, AT Antlaşması, Lizbon Antlașmast.

\section{Abstract}

The Policy behind the protection of intellectual and industrial property (IP) rights is to provide a balance between the competing interest of creator, investor and society. This balance has been achieved by the attribution of exclusivity as a reward to the creators, and introducing exceptions to exclusivity in favour of society, but in the meantime obliging society to respect those exclusive rights though limited by time.

Governments always consider the protection of IP rights as an important tool for their technological and cultural developments within the framework of abovementioned policy approach, and grant protection within the limit of their national territory. Because of this territoriality approach, different national rules relating to the scope, duration and exchusivity of such rights do exist, and this very existance have become the most striking feature of IP laws. There is no doubt that such a different existance would be detrimental to the free movement of products covered by those rights, by being capable of creating obstacles within the European Community $(E C)$ in the absence of unification of national IP rules.

This article is an humble trial to answer the question of how the EC, through its Treaty provisions and case law reconciled the exclusivity and territoriality principles of IP law, with the vital principles, for instance, of free movement of goods and of competition law.

Key Words: Intellectual and industrial property rights,European Community, copyright, related rights, patents, utility models, industrial designs, trademarks, geographical indications, semiconductor chip topographies, plant breeder's rights, EC Treaty, Lishon Treaty.

\section{Giriș}

İlim ve edebiyat eserleri, müzik ve sinema eserleri, icracı sanatçılar, fonogram yapımcıları, buluşlar, marka ve tasarımlar, yeni bitki çeşitleri, yarı iletken ürün topografyaları gibi bir kısmına günlük hayatta da sıkça rastladığımız bu kavramlar, fikrî ve sınaî mülkiyet hakların konusunu oluşturan kavramlardır.

Bir eser yaratan, bir tespit veya icrada bulunan, bir buluş yapan kişilerin haklarının; ortak bir takım kavramlar oluşturmak suretiyle çağdaş anlamda korunması, 19. y. y. da mümkün olmuştur' ${ }^{1}$. Böyle olmakla birlikte fikrî ve sınaî mülkiyet haklarının korunmasında ülkesellik ilkesinin temel kural olması; bir başka ifadeyle, hakkın konusu, kapsamı, hak sahibinin yetkileri, korumadan yararlanma şartlan, koruma süresi gibi

${ }^{1}$ Bu konudaki gelişmeye: sınaî haklar konusundaki Paris Sözleşmesi (1883) ile, fikrî haklar konusundaki Bern Sözleşmesi (1886), iki uluslararası düzenleme olarak büyük katkı sağlamıştır. 
konuların içeriğinin tamamen ulusal mevzuat çerçevesinde belirlenmesi temel kuralı nedeniyle, hak sahipleri genellikle ${ }^{2}$ farklı ülkelerde farklı korumadan yararlanmışlardır.

Fikrî-sınaî hakların bu özelliği nedeniyle konu Avrupa Topluluğu (AT) açısından ayrı bir önem arzetmiştir. Zira üye devletlerin ulusal fikrî ve sınaî mülkiyet mevzuatındaki; konu, kapsam, koruma süresi, koruma şartları hakların kullanılış şekli gibi hususlardaki farklılıklar, İç (Tek) Pazarın gerçekleştirmeye çalıştığı amaçları zedeleyici sonuçlar yaratabilecek niteliktedir. Bu durum ise, AT içinde rekabetin bozulması, mal ve hizmetlerin serbest dolaşımının engellenmesi anlamını taşıyacaktır.

Oysa Avrupa Birliği (AB), AB Antlaşmasının 2. maddesinde diğer amaçların yanısıra ekonomik ve sosyal entegrasyonu ulaşılması gereken amaçlar arasında saymıştır. AB'nin bu genel amaçlan doğrultusunda AT Antlaşması; bu amaçlara, AT çerçevesinde hangi politikalar ve araçlarla ulaşılacağını 3. maddesinde somut bir biçimde vurgulamıştır. Sayılan politika ve araçlar arasında, iç pazar açısından büyük önemi olan mallarm serbest dolaşımı, rekahet ve mevzıat uyumm politikalan bulunmaktadır. Fikrî ve sınaî hak sahiplerinin haklarını kullanış şekli ile fikrî-sınaî haklar konusundaki ülkesellik ilkesinin AT'nin bu politikalarını zedelemesi, AT'nin entegrasyon hedefleri ile de bağdaşmayacak sonuçlar doğurabilecek niteliktedir.

İşte bu noktada fikrî-sınaî hak konusunun AT içinde nasıl düzenlendiği hususu önem kazanmaktadır. Kurucu Antlaşmada ${ }^{3}$ ayrıntılı biçimde düzenlenmeyen bu konu, Adalet Divanı'na büyük sorumluluklar yüklemiş ve zamanla Divan'ın yarattığı içtihatlar doğrultusunda mevzuat uyumunu sağlayıcı ikincil düzenlemeler vaz'edilmeye başlanmıştır. Bu haliyle bakıldığında, fikrî ve sınaî mülkiyet haklarının AT içindeki yeri; Topluluk Hukukunun bu alanda nasıl geliştiği, Adalet Divanı'nın bu gelişmedeki rolü, gelişmede entegrasyon düşüncesinin ne denli ağırlıklı bir yere sahip olduğu, bu düşüncenin ikincil düzenlemeler vaz'edilirken zımnî yetki ${ }^{4}$ çerçevesinde şekillenmesi, bu konuda üçüncü ülkelerle ilişkiler ve uluslararası sözleşmelere taraf olma bakımından izlemeye değer, oldukça zengin bir hukukî tablo oluşturmuştur. Kuşkusuz bu hukukî tablonun etkileri İç Pazar içinde, fikrî-sınaî hak sahipleri ve işletmeler açısından, getirilen saydamlık, netlik ve belirginlik nedeniyle oldukça olumlu olmuştur.

$\mathrm{Bu}$ nedenle AT Hukuku içinde yavaş yavaş ama oldukça kararlı bir biçimde gelişen bu alanın, izlenmeye değer olduğu düșünülebilir. Bu düşünceyle hazırlanan bu bölümde konu; genel olarak fikrî ve sınaî hak kavramı ve AT'de fikrî ve sınaî haklar olarak iki ana başlıkta ele alınmaktadır.

İk ana başlıkta fikrî ve sınaî hakların neler olduğu ve bu disiplinin, AT Hukuku açısından önem arzeden temel özellikleri vurgulanmıştır.

Ikinci ana başlıkta ise Kurucu Antlaşma'nın konuya yaklaşımı, Antlaşma'da zamanla yapılan değişiklikler de gözetilerek irdelendikten sonra, Adalet Divanı'nın bu konunun gelişmesindeki rolü ünlü davalarla birlikte ele alınmıştır. Daha sonra ise hem

\footnotetext{
2 "Bölgesel" birlikler dişında.

${ }^{3}$ Roma Antlaşması (AT Antlaşması)

+ Implied power, bkz. AT Antlaşması madde 308.
} 
fikrî haklar, hem de sınaî haklar alanında vaz'edilmiş tüm ikincil mevzuat kısa tanıtıcı özetleri ile birlikte incelenmiş, üzerinde çalışılmakta olan ikincil mevzuat taslaklarına da yer verilmiştir. Bu açıklamalar yapılırken, 1.1.2009 tarihinde yürürlüğe girmesi umulan ve $A B$ ile AT Antlaşmalarında değişiklik yapan Lizbon Antlaşmasının ilgili hükümlerine de yer verilmiştir. ${ }^{5}$

Nihayet sonuç kısmında genel bir değerlendirme yapılmıştır.

\section{Genel Olarak Fikrî ve Sınaî Mülkiyet Hakları Kavramı}

Konuya önce terminoloji açısından yaklaşmak gerekirse, bu konuda tek bir uygulamanın olmadığı görülmektedir. Bu haklar "fikrî mülkiyet hakları" ve "stnâ̂ mülkiyet haklari" şeklinde ikili bir gruplandırma ile ifade edildiği gibi; "fikrî mülkiyet haklart" bir üst kavram olarak her iki tür hakkı kapsayacak şekilde de kullanılmaktadır ${ }^{6}$.

İkili sınıflandırma ilk kez sınaî haklarla ilgili 1883 tarihli Paris Sözleşmesinde ve 1886 tarihli fikrî haklarla ilgili Bern Sözleşmesinde ayrı ayn vurgulanmak suretiyle yapılmış ve uzun yıllar bu şekilde kullanılmıştır. Bu çalışmada ikili ayırım esas alınarak açıklamalarda bulunulmuştur. Türkiye' deki yaygın kullanım şekillerinden bir diğeri de , 'mülkiyet' sözcüğüne yer vermeden fikrî ve sinâ̂ haklar biçimindeki terminolojidir. $\mathrm{Bu}$ makalenin başlangıç kısmında mülkiyet sözcüğünü de içeren terminoloji, AT Antlaşmasının 295. maddesindeki 'mülkiyet' kavramının, Adalet Divanı tarafından fikrî ve sınaî mülkiyet hakların da kapsayacak şekildeki yorumunu anlaşılabilir kılmak açısından özellikle tercih edilmiştir.

\footnotetext{
${ }^{5}$ 13.12.2007 tarihinde imzalanan Lizbon Antlaşması, önemli pek çok değişikliğin yanısıra, AB ye tüzel kişilik vermekte ve üç sütunlu yapı anlayışını sona erdirmektedir. Buna ilaveten AT Antlaşmasımı ismi 'Treaty on Functioning of the European Union $=A B$ nin Issleyişine İlişkin Antlaşma 'olarak değiştirilmektedir. Lizbon Antlaşması, daha önce hazırlanan ve artık vazgeçilen Avrupa Anayasasına Illişkin Antlaşmanın hükümlerini büyüik oranda benimsemiş ancak, 'Anayasa' sözcüğünün ulusal kamu oylarmda neden olduğu tepki nedeniyle, bu sözcïğ̈̈ kullanmaktan özellikle kaçınmıştır. Lizbon Antlaşması ile ilgili olarak dikkat edilmesi gereken önemli hususlardan biri de Kurucu Antlaşmanın tüm madde numaralarının yeniden düzenlenmesi ve büyük oranda değişmesidir. Lizbon Antlaşmasının AB Antlaşması ve AT Antlaşmasında öngördüğü bu değişiklikler, 27 üye devletin bu Antlaşmayı iç hukuklarına aktarmalan kaydıyla 1.1.2009 tarihinde yürürlüğe girecektir. Şimdiye kadar (18.3.2008 tarihi itibariyle) 27 üye devletten Slovenya, Romanya, Malta, Macaristan ve Fransa Lizbon Antlaşmasını onaylamıştır.

${ }^{6}$ Dünya Fikrî Mülkiyet Teşkilatı (WIPO) ve Dünya Tícaret Örgütü (WTO) bu şekilde kullanımı tercih etmiş teşkilatlardır. Pek çok yazar da benzer tercihi yapmıştır. Bkz. Tekinalp Ünal, Fikrî Mülkiyet Hukuku, İstanbul 1999, s. 1-5 (Güncelleştirilmiş ve Gözden Geçirilmiş Dördüncü Bası için bkz.Arıkan Basım Yayım ve Ltd. Şti, İstanbul 2005, s.1-4 ; Erel, N. Şafak, Türk Fikir ve Sanat Hukuku, Ankara 1998, s.5. Erel, "geniş anlamda fikrî haklar" kavramını, her iki hak grubunu da içerecek şekilde üst kavram olarak kullanmaktadır. AT Antlaşmasında ilk kez 30.maddede 'sınaî ve ticarî mülkiyet haklart' kavramı kullamılmış, son zamanlarda fikrî mülkiyet hakları kavramı üst kavram olarak sınaî müllkiyet haklarını da içerecek şekilde ifade edilmiştir. Bu makalede, konuyu kendi içinde anlaşılır kılmak ve tekrarlardan kaçınmak amacıyla, tarihsel kullanımdan yola çıkılarak fikrî ve sınaî mïlkiyet hakları ifadesi kullanılmıştır. Kuruca Antlaşmadaki terminolojiye aynen yer verilmiş, makaledeki yaklaşım parantez içinde sergilenmiştir.
} 


\section{Fikrî Mülkiyet Hakları}

Fikrî mülkiyet haklarını, sınaî mülkiyet haklarından ayıran en önemli özellik, hakkın "yaratma" eylemi üzerine doğması; hakkın doğumu açısından idarenin tescil işlemine gereksinim duyulmamasıdır. Bu ilke bu konudaki temel uluslararası belgelerden biri olan 1886 Bern Sözleşmesinin 5/2 maddesinde ifade edilmiş ve ulusal mevzuatı etkilemiştir.

$\mathrm{Bu}$ haklar, sınaî haklara nazaran hak sahibine; yaşam süresine ilâve olarak genellikle 70 yll gibi uzun bir koruma süresi vermektedir.

Fikrî mülkiyet haklarını eser üzerindeki haklar ve bağlantılı haklar olmak üzere iki grupta incelemek mümkündür.

\section{Eser Üzerindeki Haklar}

Bu haklar kıta Avrupa'sında özelikle Fransa'da "Author's Right = Yazarın (eser sahibinin) Hakkl" olarak ifade edilirken, Anglo - Amerikan sisteminde "Copyright" olarak adlandırılmaktadır?

Ülkemizde uzunca bir süre telif hakkı olarak ifade edilen bu haklar, 1995 yılında bağlantılı hakların, 5846 sayılı Fikir ve Sanat Eserleri Kanununa dahil edilmesinden sonra, daha yaygın bir şekilde "eser üzerindeki haklar" şeklinde ifade edilmeye başlanmıştır.

$\mathrm{Bu}$ çerçevede fikrî hak korumasından yararlanacak eserleri beş grupta saymak mümkündür:

1- İlim ve Edebiyat Eserleri ${ }^{8}$,

2- Müzik Eserleri,

3- Sinema Eserleri,

4- Güzel Sanat Eserleri,

5- İşlenme ve Derleme Eserler'.

\section{Bağlantıłı Haklar}

Fikrî haklara konu "eser" 'lerin sanatçılar tarafindan icra edilmesi, ses olarak plâk, kaset, CD gibi araçlara tespiti, radyo-TV gibi yayın organlan tarafindan yayınlanması, film yapılması, bu konularda icra, tespit ve yayın ve yapım işlemlerini yapan kişilerin emek, malî yatırım ve yeteneklerini gerektirmektedir. İşte bağlantılı haklar; icracı

\footnotetext{
Ricketson Sam, The Bern Convention for the Protection of Literary and Artistic Works, London 1987 , s. 3-8.

${ }^{8}$ Bilgisayar programlan bu başlık altında yer almaktadır.

${ }^{9}$ TV ve radyo program listeleri, telefon rehberleri gibi veri tabanları bu gruba girmektedir. Magill TV Guide Ltd ile BBC, RTE ve ITP arasında; son üç TV şirketinin, veri tabanı şeklinde düzenledikleri haftalık TV program listeleri üzerindeki fikrî mülkiyet hakkınm kötüye kullanılması ile ilgili davada, haftalık TV program listeleri işlenme eser tïrüne bir örnek olarak, AT Rekabet Hukuku uyuşmazlığına konu olmuştur. Bkz. 241/91 Magill v. BBC, ITP, RTE, ECRI. 1995. s. 743.
} 
sanatçı, fonogram (ses kaydı) yapımcısı, radyo-TV yayın organları ve film yapımcılarının icra, tespit, yayın ve yapımları üzerindeki fikrî hakları ifade etmektedir ${ }^{10}$.

"Bağlantı" sözcüğünün kullanılmasının nedeni; icra eden, tespitte bulunan, yayın ve yapım yapan kişilerin haklarının bir "eser" ile bağlantılı biçimde ortaya çıkmasından kaynaklanmaktadir.

\section{Sinaî Mülkiyet Hakları}

Sınaî mülkiyet haklarının doğumu, fikrî haklardan farklı olarak idarenin tescil işlemini gerektirmektedir. Bu gruptaki koruma süreleri, fikrî haklara nazaran daha kısadır. Örneğin patentlerde ilke olarak 20, tasanımlarda 25, yeni bitki çeșitlerinde 25, entegre devre (yan iletken ürün) topografyalarında 10 yıl öngörülmektedir.

Bu başlık altında altı grup hak bulunmaktadır:

\section{Buhuşlar ïzerindeki Patent Hakkı, Faydalı Model Hakkı}

Tekniğin bilinen durumunu aşan (yeni), bilimde bir basamak oluşturan ve sanayie uygulanabilen bulușlar bu koșulları taşıyorsa patent verilerek korunur. Bir ürün veya bir ürünün üretim usulü, yukanda ifade edilen patentlenebilirlik koşullarını karşılamışsa bu hakka konu olabilmektedir.

Yeni olmakla birlikte, bilimde bir basamak oluşturmayan buluşlar sanayie uygulanabilir olmak koşulu ile faydalı model hakkına konu olmaktadırlar.

\section{Endiustriyel Tasarm Hakkı}

Bu hak, bir ürünün tamamı, bir parçası veya üzerindeki bir süslemenin insan duyuları ile algılanan özelliklerinin bütünü üzerindeki hakkı ifade etmektedir. Tasarım hakkı, iki boyutlu desenleri ve üç boyutlu modelleri içeren geniş bir kapsama sahiptir.

\section{Marka Hakkı}

Bu hak, bir işletmenin mal ve hizmetlerini, diğer işletmenin mal ve hizmetlerinden ayıran işaretler üzerinde doğmaktadır.

\section{Coğrafi Isaretler Üzerindeki Haklar}

Belirli bir coğrafî bölge, yöre, alanla bağlantılı bir ürünün aslî bazı özelliklerinin, bu coğrafî yerin doğa ve/veya insan unsurlarından kaynaklanması halinde ürünün bu yerin ismi ile birlikte anılmasına imkân veren işaretler coğrafî işaretlerdir. Trabzon

\footnotetext{
10 Yabancı literatürde "hağlantılı hak" kavramı karşılığında iki kavram eş anlamlı olarak kullamılnaktadır. Bunlar "Neighhouring Rights - Related Rights" dır. Türk kanun koyucu 2001 yılında 5846 sayılı Kanun'da yaptığı değişiklikte icracı sanatçı, fonogram yapımısısı ve yayın evlerinin haklarım "komşu hak" olarak nitelendirirken; komşu haklara ilâveten film yapımcısının haklarını bir üst kavram olarak "hağlantıl hak" başlı̆̆ı altında toplamıştır. Bkz. $5846 \mathrm{~S}$. Kanun, $4630 \mathrm{~S}$. Kanunla değişik 1-B maddesi j ve k bendleri. Ayrıntılı bilgi için bkz. Arıkan A. Saadet, "Fikrî Haklar Bağlanıında Konışu Haklar ve Türkiye", Istanbul Barosu Dergisi, C. 70, S. 4-5-6, 1996, s.161-199; Tekinalp Ünal, a.g.e., s.254-270: Jehorem H. Cohen, "Relationship Between Copyright and Neighbouring Rights", RIDA 1990, No. 144, s. 81.
} 
ekmeği, Oltu peyniri, Şile bezi, Darjeling çayı, Porto şarabı gibi. Burada hak, diğer sınaî haklardan farklı olarak bireysel değil; o özellikleri taşıyan ürünün üreticilerine aittir.

\section{Entegre Devre (yarı iletken ïrïn) Topografyalar Üzerindeki Hak}

Elektronik eşyaların kendilerinden beklenen fonksiyonları yerine getirmelerini sağlayan ve yan iletken ürünler üzerinde oluşturulan, elektronik devre tasarımları bir sınaî hak olarak korunmaktadır ${ }^{11}$.

\section{Yeni Bitki Çeşitleri Üzerindeki Islahçı Hakkı}

Biyolojik koşullarda geliştirilen farklı, yeknesak, durulmuş ve yeni bitki çeşitleri ıslahçı hakkı kapsamında koruma konusu olmaktadır ${ }^{12}$. Tescil sırasında bitkiye/tohuma verilen isim, markaya benzer bir fonksiyon icra etmekte, koruma diğer pek çok yönü itibariyle patent korumasına benzemektedir ${ }^{13}$.

\section{Fikrî ve Sınaî Hak Disiplininin AT Hukuku Açısından Önem Arzeden Temel Özellikleri}

\section{Güçlï Inhisarî Yetkiler ve Bunların Sinırlandurılması}

Fikrî ve sınaî mülkiyet hakları, hak sahibine, belirli süre de olsa mülkiyet benzeri son derece güçlü inhisarî yetkiler ${ }^{14}$ bahşetmektedir. Fikrî haklar açısından bu yetkiler, "eseri" ve "bağlantıl hak konıısu ïrïnï" ekonomik açıdan değerlendirme imkânı veren malî yetkiler ile isim hakkı ve eserde değişiklik yapılmasını önleme, eseri ilk kez umuma arzetme gibi manevî yetkilerden oluşmaktadır. Malî yetkiler, çoğaltma, dağıtım, işleme, yayınlama gibi birbirinden bağımsız yetkileri içermektedir. Dağıtım yetkisi, eserin ve bağlantılı hak konusu ürünlerin; satışı, kiralanması, ödünç verilmesi gibi ticarî açıdan değerlendirilmesi anlamını taşımaktadır.

Sınaî haklar açısından tanınan inhisarî yetkiler de benzer şekilde; hak konusu ürïnü üretmek, ticarî işlemlere konu yapmak, sözleşme akdi için icapta bulunmak, ihraç ve ithal etmek, fiilen kullanmak, sayulan amaçlarla elde bulundurma (depolamak) olarak tanimlanmaktadır.

Lisans sözleşmelerine, her iki gruba ait bu yetkilerin bir veya birkaçının, süreli veya süresiz olarak konu yapılması mümkündür.

Sözü edilen bu güçlü inhisarî yetkilerin tanınmasının amacı, yaratıcılığın teşviki ve ödüllendirilmesidir. Bu ödüllendirmenin belli bir süre ile sınırlı olması ve sürenin sonunda hakkın kamuya mal olması; bireysel çıkarlarla kamu yararı arasındaki dengeyi sağlama düşüncesinden kaynaklanmaktadır.

\footnotetext{
11 Türkiye bu konudaki, 5147 sayılı "Entegre Devre Topografyalarının Korunması Hakkında Kamın" u 22.04.2004 tarihinde kabul etmiştir. Bkz. 30.04 .2004 tarih ve 25448 s. R.G.

${ }^{12}$ Byrne Noel, "Commentary on the Substantive Law of 1991 UPOV Convention for the Protection of Plant Varieties", London, Publication of the University of London, 1997, s. 27-40.

${ }^{13}$ Türkiye, "Yeni Bitki Çeșitlerine Ait Islakçı Haklarının Korunmasına İlişkin Kanun'u 5042 sayı ile 8 Ocak 2004 tarihinde kahul etmiştir. Bkz. 15,01.2004 tarih ve 25347 S.R.G.

${ }^{14}$ Exclusive rights
} 
Diğer yandan yine kamu yararı düşüncesiyle bu güçlü inhisarî yetkilere, mevzuatta açıkça sayılmak suretiyle istisnalar (sınırlandırmalar) da getirilmiştir. Fikrî hak konusu eserlerden alıntı yapma serbestîsi, şahsî kullanımı vs. keza sınaî haklarda da deney amaçlı kullanımlar, ilaçlarda tek reçete istisnası, tasarımlarda onarım hali gibi haller bu istisnalar arasındadir.

Ancak hak sahibinin yetkilerine getirilen bir sınırlandırma hali vardır ki AT Hukuku açısından özel bir önem arzetmektedir. Fikrî ve sınầ hakkın tükenmesi olarak ifade edilen bu "sınırlandırma" kuralı gereğince; hak sahibi, kendi rızası ile piyasaya sürülen fikrî-sınaî hak konusu orijinal malların sonraki dağıtımına, güçlü inhisarî yetkilerine dayanarak artık müdahale edememektedir. Bir başka ifadeyle, mallar üzerindeki fikrî-sınaî haklar tükenmekte ve bu mallar artık fikrî-sınaî mülkiyet haklarının değil, ticaret kurallarının idaresine girmektedir. Hak konusu malın piyasaya sürüldüğü yer; bu hakların aşağıda açıklanacak olan "ülkesellik" özelliği ile birlikte değerlendirildiğinde, hakkın tükendiği coğrafî alanın belirlenmesi açısından da önem arzetmektedir. Bu konuda kanun koyucular, fikrî-sınaî hakkın "ulusal" ya da "uluslararası tükenme" kuralından hangisini seçtiklerini, mevzuatta kullandıkları dil ile belirgin hale getirmektedirler ${ }^{15}$. Yapılan tercih;paralel ithalatın, fikrî ve sınaî hakların tanıdığı güçlü inhisarî yetkilere dayanılarak önlenebilmesi ya da önlenememesi gibi sonuçlar doğurduğundan, ticaret açısından büyük önem arzetmektedir.

\section{Fikrî ve Sinaî Hakların Ülkeselliği}

Fikrî ve sınaî mülkiyet haklarının ülkeselliği; koruma şartları ve hak sahibine tanınan yetkilerin, ülkelerin coğrafî sınırları içinde uygulanan ilgili ulusal mevzuatın tanıdığı kapsam çerçevesinde geçerli olması ve uygulanması anlamını taşımaktadır.

$\mathrm{Bu}$ ilkenin iki önemli sonucu bulunmaktadır. Bunlardan ilki, korumanın ancak, koruma şartı olarak aranan eylemin ${ }^{16}$ gerçekleştiği ülkedeki ulusal kanunla belirlenmesidir. İkincisi ise, bu şekilde belirlenen ülke kanununun sağladığg korumanın doğal olarak o ülke coğrafî alanı ile sınırlı olmasıdır.

Fikrî-sınaî hakların "ülkesellik" ilkesi, birden çok üye devletin oluşturduğu AT ve AT'nin entegrasyon hedefleri açısından gerçek bir risk oluşturmuştur. Adalet Divanı'nın, bu riskin üstesinden gelmek için, "ülkesellik" ilkesini, nasıl bir "bölgesellik" ilkesi haline getirdiği hususu; Divan'ın Kurucu Antlaşma hedeflerini gözeterek, AT hukukunu nasıl şekillendiği ve geliştirdiğinin çarpıcı örnekleri arasında yer almıştır.

\footnotetext{
${ }^{15}$ Örneğin, fikrî-sınaî hak konusu malın "ülke sımırlaı içinde piyasaya sürülmesi"” ifadesi, ulusal tükenme ilkesinin benimsendiğini gösterirken; "dünyanın herhangi bir yerinde piyasaya sürrülmesi" ifadesi uluslararası tükenme ilkesinin tercih edildiğini ifade etmektedir. Bu konuda AT'nin yaptığı tercih aşağıda aynca irdelenecektir.

${ }^{16}$ Bu eylem, sınaî haklar açısından "tescil" işlemini ifade ederken; fikrî haklar açısından, o ülke toprağında veya o ülkenin tarafi bulunduğı uluslararası sözleşmelere taraf ülke topraklarında "umuma açıklama" veya "bulunma" şeklinde gerçekleşmektedir. Bu durumda bir orijinal eserin Bern Sözleşmesine taraf bir ülkede yayımlanması, Sözleşmeye taraf tüm ülkelerde, her bir ülkenin ulusal kanunu çerçevesinde koruma sağlamaktadır.
} 


\section{Avrupa Topluluğunda Fikrî ve Sınaî Mülkiyet Hakları}

AT de fikrî ve sınaî mülkiyet haklarının düzenleme ve gelişme sürecini; Kurucu Antlaşma'nin konuya yaklaşımı, Adalet Divanı'nın bu konudaki rolü ve nihayet ilgili ikincil düzenlemeleri esas almak suretiyle incelemek, konunun tarihsel gelişme seyrine de uygun olacaktır.

\section{Kurucu Antlaşmanın Konuya Yaklaşımı}

Avrupa Birliği'nin Birinci Sütunu içinde yer alan fikrî ve sınaî mülkiyet hakları, AT Antlaşması'nda; konusu, kapsamı ve koruma şartları ile birlikte ayrıntılı biçimde düzenlenmemiştir.

$\mathrm{Bu}$ konunun Kurucu Antlaşma'da ayrıntılı düzenlenmesí yaklaşımı, AT Antlaşması'nda değişiklik yapan 1993 Maastricht, 1999 Amsterdam ve 2003 Nis Antlaşma'larında da sürdürülmüştür ${ }^{1 \text { ? }}$.

Kurucu Antlaşma'nın konu ile bağlantılı maddelerine geçmeden önce gerek AB Antlaşması'nın, gerek AT Antlaşması'nın, bu bağlantıya ışık tutucu nitelikteki bazı maddelerine değinmekte yarar bulunmaktadır.

AB (Maastricht) Antlaşması'nın 2. maddesi Birliğin amaçlarını sayarken; iç sinırlart kaldırarak, ekonomik ve sosyal dayanışmayl güçlendirerek, ekonomik ve parasal birliği tek parayı 'da içerecek şekilde sağlayarak; ekonomik ve sosyal gelişmeyi, istihdamı arttırmanın ve dengeli ve sürdürülebilir bir kalkınmayı gerçekleştirmenin (diğer amaçların yanı sıra) önemli hedefler arasında bulunduğunu vaz'etmektedir. Ekonomik ve sosyal entegrasyon olarak formüle edilebilecek olan bu amaç, Birliğin Birinci sütununu oluşturan AT Antlaşma'sının da 2. maddesinde vurgulanmıştır. AT Antlaşması, bu amacı sağlayıcı araç ve politikalarını 3. maddesinde tek tek saymıştır. Gümrük birliği ve iç pazarın tesisinden, turizm alanında tedbirler almaya kadar uzayan ve toplam 21 adet olarak vurgulanan bu politikalardan üç tanesi fikrî-sınaî mülkiyet hakları açısından özel önem arzetmektedir.

Bunlar:

- Diğer unsurların yanı sıra "malların" serbest dolaşımını önleyen tüm engellerin kaldırıldı̆̆ bir iç pazarın tesisi,

- İç pazardaki rekabeti bozmayan bir sistemin tesisi,

- Ortak pazarın işlevselliğinin gerektirdiği ölçüde üye devletler mevzuatının uyrumlaştırılması.

\footnotetext{
${ }^{17} \mathrm{Bu}$ konuda özel hüküm getirme yaklaşımı ilk kez Birliğin Temel Haklar Şartının Özgürlükler başlıklı II. Bölümünde, fikrî ve sınaî hakların korunacağı "intellectual property shall be protected" ifadesi ile 17/2. maddede açıkça vaz'edilmiştir. Nihayet Lizbon Antlaşması da AT Antlaşması içinde konuyu yeni bir hükümle 97 a maddesi ile VI Kısımda özel olarak düzenlemiştir. Lizbon Antlaşmasının $\mathrm{AB}$ Antlaşması ve $\mathrm{AT}$ Antlaşmasında öngördüğü bu değişiklikler, 27 üye devletin bu Antlaşmayı iç hukuklarına aktarmaları kaydıyla 1.1.2009 tarihinde yürürlüğe girecektir.
} 
Bu üç politika önemlidir, çünkü fikrî ve sınaî haklara konu mallar, aynı zamanda iç Pazar açısından serbest dolaşıma konu olan mallar niteliğindedir. Buna bağlı olarak üye devletler fikrî-sınaî hak mevzuatının ülkesellik ilkesi ve her ülkenin bu konudaki mevzuatının farklılıkları, iç pazarın gerçekleştirilmesi açısından bir risk oluşturabilir. Diğer yandan fikrî ve sınaî hak sahiplerine tanınan güçlü inhisarî yetkilerin lisans sözleşmelerinde veya genel olarak kullanım şekli rekabet politikası açısından hassas bir konu olacaktır. Nihayet, üye ülkelerin bu konudaki farklı mevzuatı, AT düzeyinde bir mevzuat uyumunu kaçınılmaz kılacaktır.

\section{Lizbon Antlaşması Öncesi AT Antlaş̧masının Konuya Yaklaşımı}

İște bu politikaların ışığı altında AT Antlaşması'nda fikrî ve sınaî haklar konusunda yorum yapilabilmesine hukuken dayanak sağlayan dört grup madde bulunmaktadır. Bunlar: AT Antlaşması'nın üye devletlerdeki mülkiyet sistemine saygılı

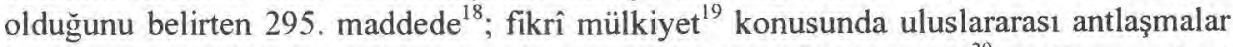
imzalama yetkisinin Topluluğa ait olduğunu ifade eden $133 / 5$. madde ${ }^{20}$; malların serbest dolaşımı ile ilgili yasaklayıcı hükümler getiren 28 ve devamı maddelerinin ${ }^{21}$ istisnası niteliğinde olan 30 , madde ${ }^{22}$ ve nihayet iç pazarda rekabeti bozucu anlaşma, karar ve uyumlu davranışları yasaklayan 81 . madde ${ }^{23}$ ile hâkim durumun kötüye kullanılmasını yasaklayan 82 . maddedir ${ }^{24}$.

AT Antlaşması'nın 30 ve 295. maddelerinde; üye devletlerin fikrî ve sınaî hak mevzuatına Antlaşma'nın saygılı olduğunu ifade eden gözetici bir yaklaşım benimsenmiştir. Özellikle 30. madde; Antlaşma'nın miktar kısıtlaması ve eş etkili

18 Eski 222. madde. AT Antlaşması'nın 295. madde hükmü, Anayasa Taslağı'nın "Birliğin Fonksiyonlarn ve Politikaları" "başlıklı III. Kısmının 425. maddesinde aynen muhafaza edilmiş, bu yaklaşım Lizbon Antlaşmasında da aynen sürdürülmüş olup, Lizbon Antlaşmasının yürürlïiğe girmesi halinde $A B$ Antlaşmasının İşleyişine İlişkin Antlaşmada 345. madde olarak yerini alacaktır. "Mïlkiyet" kavramının içinde fikrî ve sınaî mülkiyet haklarının tamamının bulunduğu Adalet Divanın içtihatlarında açıkca benimsenmiştir.

${ }^{19}$ Bu kavram, sunaî hakları da içeren üst kavram şeklinde kullanılmış olup, madde metnine Amsterdam Antlaşması ile dahil edilmiştir. Değişiklikten önce bu konu, üye devletlerle Topluluğun bir arada kullandığı "ortak bir vetki alanı" idi.

20 Eski 228. madde. Bu konu Anayasa Taslağı'nun "Birliğin Fonksiyonlar ve Politikalan" başlıklı III. Kısmının 315/4. maddesinde paralel şekilde dïzenlenmiş, Lizbon Antlaşmasımı 188 c maddesinde ifadesini bulan bu hüküm, Lizbon Antlaşmasının onaylanması halinde 207. madde olarak sistemde yerini alacaktır.

${ }^{21}$ Eski 30 ve devamı maddeler. Bu konu, Anayasa Taslağı'nın III. kısmınm 153. maddesinde düzenlenmiş, Lizbon Antlaşmasında aynı hükümılerin 34-36. maddeler olarak sistemde yer alacağı vurgulanmıştır.

22 Eski 36. madde. Bu konu, Anayasa Taslağı'nun III. kısmınm 154. maddesinde düzenlenmiş, Lizbon Antlaşmasında bu madde yine 36. madde olarak muhafaza edilmiştir.

${ }^{23}$ Eski 85. madde. Bu konu Anayasa Taslağı'nın III. kısmanın 161. maddesinde dïzenlenniş, Lizbon Antlaşmasında 101 madde numarasını alması öngörülnüuş̧ür.

${ }^{24}$ Eski 86. madde. Bu konu Anayasa Taslağı'nın III. kısmmm 162. maddesinde dïzenlenniş, Lizbon Antlaşmasında aynı konunun 102 madde numarasını alması vurgulanmıştır. 
tedbirlere ${ }^{25}$ getirdiği yasaklamanın “... ticarî ve sınaî mülkiyetin korunması nedenlerinin haklı kıldığı ..." hallerde uygulanmayacağını ifade etmekle birlikte "... bu yasaklama veya kusttlamaların üye devletler arası ticarete keyfi bir ayrım ya da gizli bir kusitlama getireme... "yeceğini de temkinli bir şekilde vurgulamıştır. Diğer taraftan Antlaşma'nın 81 ve 82 . maddeleri; sahip olduklan güçlü inhisarî yetkiler nedeniyle, bazı hallerde hâkim konumda sayılabilen fikrî ve sınaî hak sahiplerine, Antlaşma'nın rekabet hükümlerini gözetme sinyalini verici nitelikte düzenlenmiştir.

Konuyla ilgili ayrıntılı hükümlerin bulunmadığı bu genel çerçeve içinde, konuyla bağlantılı tüm bu maddeleri, entegrasyon hedefinden yola çıkarak bağdaştırmak Adalet Divanı'na düşmüştür.

\section{Lizbon Antlaşmasındaki Yeni Düzenleme}

Fransa ve Hollanda' daki olumsuz yaklaşımla sonuçlanan referandumlar nedeniyle Anayasa Taslağının yürürlüğe girmeyeceğinin anlaşılması üzerine hazırlanan Lizbon Antlaşması ; Kurucu Antlaşmada yer alan ve yukarda ifade edilen diğer hükümleri içerik olarak aynen muhafaza etmekle birlikte, ilk kez bu konuda özel bir hükmü Kurucu Antlaşma metnine yeni bir madde numarası ile lafzen de dahil etmiştir. AT Antlaşmasının İç Pazarla ilgili hükümlerinin yer aldığı ve İç Pazarın sağlıklı işleyebilmesi için üye devlet mevzuatının uyumlaştırılmasını içeren VI. Kısmında yer alan 97a maddesi, Lizbon Antlaşmasının yürürlüğe girmesi halinde 1.1.2009 tarihinden itibaren, AB Antlaşmasının İşleyişine İlişkin Antlaşmada 118 madde numarası altında, aşağıdaki ifade ile yerini alacaktır:

Fikrî (ve Sınaî ) Mülkiyet ${ }^{26}$

118. madde:

'İC Pazarın kurulması ve işleyişi bağlamında Avrupa Parlamentosu ve Konsey; olağan yasama usulü çerçevesinde fikrî (ve sinaî) mülkiyet haklarma tüm Birlik içinde yeknesak bir koruma sağlamak ve Birlik düzeyinde merkezileştirilmiş yetkilendirme, koordinasyon ve denetleme oluşturmak için Avmupa fikrî (ve sınâ̂) mülkiyet haklarını yaratic tedbirleri alır.

Konsey, Avrupa fikrî (ve sınâे) mülkiyet haklar ile ilgili dil düzenlemelerini, özel yasama usulü çerçevesinde tüzükler aracılı̆̆ ile düzenler. Konsey,Avrupa Parlamentosuna danıştıktan sonra oybirliği ile hareket eder.'

Maddede benimsenen yaklaşım aslında, Lizbon Antlaşmasına kadar İç Pazarla ilgili maddelerden yola çıkarak Adalet Divanının geliştirdiği içtihatların ışığı altında düzenleme yapma yetkisinin Toplulukta olduğu kuralının, hukuken fikrî ve sınaî mülkiyet hakları açısından birkez daha ama açıkça ifade edilmesidir. Dolayısı ile yeni olan içerik değil, bunun özel bir maddede düzenlenmiş olmasıdır.

25 "Eş etkili tedbir" kavramı içerisine, üye devletler arasındaki ticareti doğrudan veya dolaylı etkileyecek tüm kuralların dahil olduğu, ilk kez Dassonville davasında (bkz. 8/74, ECR 1974, s. 837) Divan tarafindan ifade edilmiştir.

${ }^{26}$ Parantez içindeki kavramlar makalede kullanılan terminolojiye uyum sağlamak için yazar tarafindan ilave edilmiş olup, madde metni de yazar tarafindan çevrilmiştir. 
Maddeye göre karar organı olan Konseyin iki tür yetkisi bulunmaktadır:

1- Birliğe üye ülkeler arasında, bu konudaki üye devlet mevzuatinı uyumlaştırmayı sağlayıcı düzenlemeler yapmak, ki bu konu bir uyumlaştırma aracı olan direktiflerle sağlanacaktır.

2- Birlik düzeyinde fikrî ve sınaî mülkiyet hakları yaratmak, ki bunlar Avrıpa fikrî (ve sınaî) miilkiyet hakları adını alacaktır. Örneğin Topluluk Markası, Topluluk Tasarımı gibi. Şimdiye kadar Topluluk düzeyindeki bu hakların başında 'Topluluk' kelimesi kullanılırken bundan sonra Lizbon Antlaşmasının genel yaklaşımına uygun olarak bu kavram, tüm üye devletleri kapsayacak tek bir hakkı ifade etmek üzere ' Avrupa' kelimesi ile ifade edilecektir. Dolayısı ile Avrupa düzeyindeki patent, marka , tasarım, faydalı model gibi hakların tesisinde gerekli olan tescil mekanizmasının merkezileștirilmesi, başvuru ve benzer idari konuların koordinasyonu, ayrica bu hakların kounmasını da içerecek şekilde tüm denetleme mekanizmalarının oluşturulması, Birlik düzeyinde etkiler yaratmaya en uygun tasarruf türü olan tüzükler aracılığı ile yapılacaktır. Nitekim bu konu, maddenin son paragrafinda tüzüklere atıfta bulunulmak suretiyle açıkça vurgulanmıştır. Son paragraf, Topluluk Patentinin yaratılmasında 1965 li yıllardan bu yana hazırlanan düzenlemelerin yürürlüğe girmesinde sorun oluşturan konular arasinda yer alan 'dil' hususuna özel bir yer vermiştir.Bu yaklaşım çerçevesinde Konsey, Avrupa fikrî (ve sınâ̂) mülkiyet hakları ile ilgili dil düzenlemelerini Avrupa Parlamentosunun da görüşü alınmak kaydı ile tüzükle yapacaktır. Böylece şimdiye kadar dil konusunda sağlanamayan uzlaşmanın, çözüm yeri olarak açıkça Konsey yetkilendirilmiştir. Maddede 'oybirliği' şartının olması burada da hayli çekişmeki tartışmaların olacağını gösterse de Antlaşma konuya, uzlaşma yeri ve tasarruf türü açısından netlik getirmiştir.

\section{Adalet Divanı'nın Fikrî ve Sınaî Haklara Yaklașımı}

\section{Divan' in Geliştirdiği İlkeler}

Adalet Divanı önüne gelen davalar veya ön karar başvuruları nedeniyle, 1966'lı yıllardan itibaren; bir üye devlette ikâmet eden fikrî-sınaî hak sahibinin, diğer üye devletten yapilacak paralel ithalatı bu haklara dayanarak engellemesine tanik olmaya başlamıştır.

Divan (Kurucu Antlaşma'nın 2. maddesinde ifade edilen entegrasyonun sağlanabilmesi için, malların serbest dolaşımı ilkesinden taviz verilmemesi gerektiği inancıyla), fikrî-sınaî hak sahibinin bu haklara dayanarak paralel ithalatı engellemesini bertaraf ederken; bu yargısal yaklaşımını, bu haklar konusunda ulusal mevzuatın gözetilmesi gerektiğini vurgulayan Antlaşma'nın 30 ve 295. maddeleri ile bağdaștıracak formüller aramaya başlamıştır. Fikrî ve sınaî hakkın "varlığl", "kullanımı", "özü", "işlevi", "tükenme" ve "orijini" başlıkları altında geliştirilen bu formüller Divan tarafindan, ilke olarak așağıdaki biçimde açıklanmıştır:

Fikrî ve Sınaî Hakkın Varlığı (existence) İlkesi

Fikrî ve sınaî hakların üye devlet mevzuatında düzenleniş şekli, var oluş biçimi olarak ifade edilen bir ilkedir. Divan, hemen hemen tüm davalarda hakkın bu var oluş 
biçimine saygılı olduğunu, bunu irdelemediğini belirtmiştir ${ }^{27}$. Hakkın varlığına gösterdiği bu saygı ile Divan, Antlaşması'nın 30 ve 295. maddesinde belirtilen ilkeleri çiğnememektedir.

Fikrî ve Sınaî Hakkın Kullanımı (exercise) İlkesi

Fikrî ve sınaî hakların üye devlet mevzuatındaki düzenlenmiş biçimi ve hak sahibinin bundan doğan yetkilerinin varlığına saygılı olan Divan, bu hakların kullanış biçiminin, malların serbest dolaşımını tehlikeye sokması veya rekabet kuralları ile çelişmesi halinde, Toplulukta entegrasyonun korunması amacı ile her zaman denetleme yetkisi dahilinde olduğunu belirtmiştir ${ }^{28}$.

Fikrî ve Sınaî Hakkın Özü (spesific subject matter) İlkesi

Divan, 30. maddede, fikrî-sınaî haklar açısından malların serbest dolaşımına getirilen istisnanın aslında fikri-sınaî hakların özünü korumak için getirildiğini belirterek; patentler açısından bu özün, patent sahibine (yaratıcı faaliyeti nedeni ile) patenti üzerinde üretmek, ilk kez piyasaya sürmek, ihlallere tavır koymak konusunda inhisarî yetkiler verilerek ödüllendirmeyi gerektirdiğini vurgulamıştır ${ }^{29}$.

Marka açısından ise markanın, malın orijini konusunda bir garanti oluşturması nedeni ile, marka sahibinin malın orijinal şartlarını etkileyecek müdahaleleri önleme yetisinin bulunduğunu, bu yetkinin marka hakkının özünü oluşturduğunu belirtmiştir ${ }^{30}$.

Divan'ın hakkın özünü belirleme ilkesini her davada saptamadığı görülmektedir. Bu eğilim özellikle fikrî hak davalarında dikkat çekmiştir ${ }^{31}$.

Divan'ın hakkın özü açısından eleştirilen bir diğer yaklaşımı, bir fikrî-sınaî hakkın hak sahibine birden çok yetki verdiği durumlarda (örneğin fikrî hakkın çoğaltma, kiralama, ödünç yetkileri gibi), hakkın özü niteliğindeki bu yetkilerin Divan tarafından her olayda bir bütün olarak liste halinde belirlenmeyip, önüne gelen davaya göre ilgili bir tanesinin (örneğin bazen kiralama bazen ödünç yetkisinin) vurgulanmasıdır ${ }^{32}$.

Hakkın özünü belirlediği davalarda ise, bu belirlemeyi yaparken bir üye devlet fikrî-sınaî hak kanununa veya kanunlarına atıfta bulunmamış, Topluluk mahkemesi olarak kendi özgün yorumunu yapmıştır.

\footnotetext{
$2^{2-}$ Nitekim Keurkop v. Nancy Kean 144/81 davasında, Adalet Divanı, Nancy'nin ABD'de tasarım olarak $1977^{\prime}$ lerden bu yana korunan bayan el çantası tasarımını, Benelux Sınaî Hak Kanunu'na dayanarak Hollanda'da tescil ettirmesinin geçerliliğini hiç tartışmamıştır. Bkz. ECR 1982, s.2853.

${ }^{28}$ Bkz. Terapin v. Terranova 119/75, ECR 1976, s. 1039. Hakkın kullanım şekli ilkesine daha çok rekabet kurallarımm ihlal edildiği davalarda başvurulmuştur. Bkz. Consten v. Grundig 56-58/64, ECR 1966, s. 299; Parke Davis v. Centrafarm 15/74, ECR 1969, s. 95; Sirena v. Eda 40/70, ECR 1971, s. 69.

${ }^{29}$ Bkz. Centrafarm v. Sterling Drug 15/74, ECR 1974, s. 1147.

${ }^{30}$ Bkz. Centrafarm v. American Home Products 3/78, ECR 1987, s. 1823; Centrafarm v. Wintrop 16/94, ECR 1974, s. 1194.

${ }^{31}$ LOEWENHEIM, U.: Intellectual Property Before The European Court of Justice, IIC 1995, Vol. 26, no. 6, s. 838 .

${ }^{32}$ Bkz. WYATT, Derrick-DASHWOOD, Alan: The substantive Law of the EEC, London 1991, s. 481.
} 
Fikrî ve Sınaî Hakkın İșlevi (function) İlkesi

Özellikle markalar ile ilgili davalarda sıkça kullanılan bu ilke ile hakkın korunmasındaki amaç vurgulamaya çalışılmıştır. Örneğin markalarda hak sahibinin şöhretinin korunması hakkın özünü oluştururken, tüketicinin de karışıklık ve aldanmadan korunması markanın işlevi olarak tanımlanmıştır ${ }^{33}$.

Fikrî ve Sınaî Hakkın Tükenmesi (exhaustion) Illkesi

Fikrî ve sınaî haklar konusu bir mal ile ilgili bir paralel ithalat olayında Divan, malın Topluluk içinde herhangi bir yerde hak sahibinin rızası ile piyasaya sürüldüğü anda, fikrî ve sınaî hakların verdiği yetkinin tükendiğini, bu nedenle hak sahibinin paralel ithalatı önleyemeyeceğini belirtmektedir. Divan'ın bu yaklaşımı ile ulusal tükenme ilkesi, Topluluk çapında tükenme ilkesine dönüşmüş bulunmaktadır. Bir başka deyimle Topluluğa üye 25 devlet, fikrî-sınaî hakların tükenme açısından tek bir ülke toprağ 1 gibi işlem görmektedir.

Fikrî ve Sınaî Hakkın Orijini (origin) İlkesi

Divan'ın markalar açısından 1974 yılında geliştirdiği bir ilke olup; aynı orijinden gelen markalardan birinin hak sahibinin rızası dışında (devletin el koyması gibi) el değiştirmesi halinde dahi, markanın orijininin aynı olması nedeni ile paralel ithalatın önlenemeyeceği esasına dayalıdır ${ }^{34}$.

Diğer haklarda rıza ilkesine dikkat eden Divan'ın bu kararı çok büyük eleştirilere neden olmuş nihayet, 1989 yılında açılan bir diğer dava ile Divan, rzza ve marka hakkının özü ve işlevi ilkelerinden yola çıkarak, 1974 yılındaki görüşünden vazgeçmiş ve aynı orijinden gelse bile rıza dışında el değiştirme hallerinde, marka hakkının özünün korunması için paralel ithalatın önlenebileceğini vaz'etmiştir ${ }^{35}$. II. HAG davası ile hakkın orijini ilkesi 1974 yllında belirtilen çerçevede otorite olmaktan çıkmış

${ }^{33}$ Bkz. CNL-Sucal NVV. HAG AG. 10/89, ECR. 1990, I. s. 3711. Divan'm hakkın özï ve hakkın işlevi ilkelerini getirmesinin nedeni, 30. maddede anılan malların serbest dolaşımma getirilecek istisnanın ancak, fikrî ve smaî hakların (özü ve işlevinin) korunması için haklı görülecek durumlarda uygulanabileceği gerçeğinden kaynaklanmaktadır.

${ }^{34}$ İlkenin doğmasına neden olan olayda: Almanya ve Belçika'da, Alman marka sahibi tarafından tescil edilen HAG markasının, II. Dünya Savaşı sonunda düşman malı olarak, Belçika hükümetince el konulup daha sonra Van Zulyen ailesine satılması ve 1973 yllında Alman HAG ürünlerinin (kafeinsiz kahve), Belçika piyasasına girmesinin Van Zulyen tarafindan tescilli hak markasına dayanılarak önlemek istenmesi, davanın Adalet Divanı'na refere edilmesine (Antlaşma'nın 177. maddesi çerçevesinde) neden olmuştur. Bkz. Van Zulyen Freres v. HAG AG. 192/73, ECR 1974 s. 731. Divan bu davada ne rıza ne de markanın özü ve işlevi üzerinde durmuștur.

${ }^{35}$ İkinci HAG davası diye anılan bu olayda Belçika HAG'ın sahibi Van Zulyen, bu marka ïzerindeki hakkını ve işletmesini SA-CNL-Sucal NV. Şirketine satmıştır. HAG markasının yeni sahibinin aynı markalı kahveyi Alman piyasasına ihraç etmek istemesi üzerine bu kez Alman HAG markasının sahibi itiraz etmiştir. Bkz. SA-CNL-Sucal NV. v. HAG AG. 10/89, I ECR 1990, s. 3711. Dava devam ederken Alman HAG Belçika HAG'1 devralsa da Divan yukarıdaki gerekçe çerçevesinde paralel ithalatın önlenmesini Antlaşma'nın 36. maddesinde anılan istisna kapsamında öngörmüştür. 
bulunmaktadır ${ }^{36}$. Divan'ın diğer fikrî-sınaî haklarda aradığı "rıza ile piyasaya sürme" ve "hakkın özï, işlevi" kriterleri böylece aynı orijinden gelen markalı ürïnlerde de uygulamaya başlanmıştır $3^{3-}$.

\section{Adalet Divanı'nın Bazı Örnek Kararları}

\section{Centrafarm v. Sterling Drug Davasi ${ }^{38}$}

Olayda Amerikan Sterling Drug firması, idrar yollan enfeksiyonu ile ilgili bir ilaç için, hem Hollanda hem de İngiltere'de patent alarak, bu iki ülkede aynı ilaç için, üretim ve satış lisansı vermiştir.

Ingiliz hükümetinin ilaç fiyatlarında izlediği sosyal politika nedeni ile, İngiltere'de aynı ilacin Hollanda'dakinin yarı fiyatına satılmasından yararlanan Centrafarm (paralel ithalatçı), bu ilaçları Hollanda'ya ithal etmek istemiştir. Hollanda'daki yavru Sterling firmasının, paralel ithalatı patent hakkına dayanarak önlemesi üzerine açılan davada konu, Adalet Divanı'na ön karar yolu ile gelmiştir.

Divan patentli malı ithalatın yapıldığı Topluluk ülkesinde (Hollanda) ilk kez rızası ile (yavru şirketi veya lisans vererek) piyasaya sürüldüğï anda Sterling firmasının alacağı en yüksek kârı aldığının varsayılması gerektiğini belirtmiştir. Hakkın tükenmiş olmasına rağmen, İngiltere'den gelen ve yine aynı firmanın lisanslı üreticisi tarafından üretilen malların üçüncü kişilerce (Centrafarm), Hollanda'ya ithalatının önlenmesinin, Roma Antlaşması'nın malların serbest dolaşımı ilkesi ile bağdaşmayacağı vurgulanmıştır.

Divan, piyasasında malın ucuz olduğu ülkede patent korumasının mevcut olmamasını, patentli mal, bu ülkede hak sahibinin rızası ile piyasaya sürülmüş olmak kaydı ile paralel ithalatın önlenmesi açısından bir engel olarak görmemiştir ${ }^{39}$.

Adalet Divanı'nın patentler ile ilgili olarak paralel ithalata hoşgörülü bakmadığı durum, patentli ürünün, hak sahibinin rızast dışında piyasaya sürülme halleridir. Ülkeler, patent verdikleri buluşların genellikle o ülkede imal edilerek kullanımını, patent kanunlarında şart koşmaktadır. İşte patent almasına rağmen, patentini kullanamayan hak sahibi, istemese de patent konusu buluşunun imalatının, idare tarafundan üçüncü kişilere zorunlu lisans yolu ile verilmesi durumu ile karşılaşabilmektedir. Adalet Divanı bu tür olaylarda, hakkını o ülkede rızası ile

\footnotetext{
${ }^{36}$ HAG davaları hakkındaki yorum için bkz. ROTHNIE, A. Warwick: "HAG II: Putting the Common Origin Doctrine to Sleep", European Intellectual Property Review 1991, no. I, s. 2431: Alexandre Willy: Case Comment on HAG II, CMLRev., 1991, Vol. 28, s. 681-697.

37. Divan, 22 Haziran 1994 tarihinde verdiği IBT v. Ideal Standart C-9/93 karannda, aynı orijinden gelen markanın (Ideal Standart), el koyma nedeni dışında rızaya dayalı el değiştirmeler ile birbirinden bağımsız birçok kişiye aidiyeti konusu üzerinde durmuş ve markanın işlevinin korunması için, bu nitelikteki paralel ithalatın önlenebileceğini öngörmüş̧tür.

${ }^{38}$ 15/74 ECR 1974, s. 1147.

${ }^{39} \mathrm{Bkz}$. İtalya'nın ilaca patent vermediği yıllarda Hollanda'da patentli yüksek tansiyon ilacının, bizzat patent sahibi tarafindan İtalya'da piyasaya sürülmesi ve daha sonra bu ilaçlann tekrar paralel ithalat yolu ile Hollanda'ya sokulması istenmesi hakkında Merck v. Stephar 187/80, ECR 1981, s. 2063.
} 
kullanmayan patent sahibinin, diğer üye devletlerden yaplacak, aynı patent konusu malların paralel ithalatını önleyebileceğini belirtmektedir ${ }^{40}$.

Adalet Divanı zorunlu lisanslar konusunda patent hakkı sahibi lehine böyle bir karar vermekle birlikte daha sonra, İtalya ve İngiltere'nin patent kanunlarındaki zorunlu lisans hükümlerini uygulayış biçimleri nedeniyle Roma Antlașması'nın 30. maddesini ihlal ettiklerini vurgulamışıtır ${ }^{+1}$.

Olay, Italya ve Íngiltere Patent Kanunlarının, patent hakkı sahibinin patentli buluşu orada kullanmayıp, diğer ülkeden ithal etmesi halinde Patent Enstitüsü'nce, üçüncü kişiye zorunlu lisans verilebileceği hükmünü vaz'etmelerinden kaynaklanmıştır. Kısaca İtalya ve İngiltere, patentli ürünün ithalatını patentin ülkede kullanılması anlamına gelmediği şeklinde yorumlamışlardır ${ }^{42}$. Komisyon tarafindan Roma Antlaşması'nın 169. maddesine dayanılarak açılan davalarda Adalet Divanı:

- Patent hakkının kullanılması nedeni ile üye devletlerin zorunlu lisans verme hakkı her zaman bulunmaktadır. AT, Roma Antlaşması'nın 222. maddesi çerçevesinde üye devletin bu düzenlemesine saygılıdır. Ancak,

- Patent hakkı sahibi patentli ürünü fiilen o ülkede imal etmek yerine diğer üye devletten ithal etmek sureti ile kullanıyor ise bu ithalatı kullanma saymayarak, üçüncü kişilere zorunlu lisans vermeye kalkmak, Roma Antlaşması'nın yasakladığı "miktar kisitlamasına es etkili tedbir" koymak anlamina gelir. $\mathrm{Bu}$ ise, malların serbest dolaşımını öngören Antlaşma'nın 30. maddesinin ihlali sonucunu doğurur şeklinde karar vermiştir ${ }^{43}$.

Centrafarm v. Wintrop ${ }^{4+}$

Olayda Amerikan şirketi, ilaçlarda kullandığı Negram markasını Hollanda ve İngiltere'de tescil ettirerek, anılan ilacı bu iki ülkedeki yavru şirketleri aracılığı ile piyasaya sürmüştür. Paralel ithalatçı Centrafarm şirketi, İngiliz piyasasından aldığı Negram markalı ilaçları, aynı markalı ilaçların bulunduğu Hollanda piyasasında satmak istediğinde, Hollanda'daki yavru şirket tarafindan, marka hakkına dayanılarak durdurulmak istenmiştir.

Ön karar yolu ile görüşü sorulan Adalet Divan, Hollanda ve İngiltere piyasalarında Negram markalı ürünlerin piyasaya sürülüşünün, hak sahibinin rızası ile yavru şirketler tarafından yapıldığını, bu nedenle hakkın tükendiğini belirterek, Hollanda' daki yavru şirketin paralel ithalatı önleyemeyeceğini vurgulamıştır.

\footnotetext{
${ }^{40}$ Bkz. Pharmon v. Hoechst 19/84, ECR 1985, s.2281.

${ }^{41}$ Bkz. Commission v. UK, 30/90, I ECR 1992, s.829 ve Commission v. Italy $235 / 89$, I ECR 1992, s. 777.

42 Ispanya ve Portekiz kanınlan da benzer hükümıler taşıdığından, bu iki ülke de Ingiltere ve İtalya yanında davaya katılmıștır.

${ }^{43}$ Adalet Divanı, ithalatın kullanma anlamına geldiğine ilişkin bu içtihadın, AT için vaz’ederken: DTÖ TRIPs Anlaşması da 27. maddesinde aymı kuralı Anlaşma ya taraf üye devletler açısından getirmiștir.

${ }^{4}$ 16/74, ECR 1974, s. 1194.
} 
Temel kural böyle olmakla birlikte, markalar ile ilgili paralel ithalatlarda bazı özellikler yaşanmıştır. Bu çerçevede paralel ithalatçı, ithalatta bulunduğu ülkenin genellikle paketleme konusundaki idarî düzenlemelerinden kaynaklanan nedenler yüzünden, ithal konusu orijinal (genuine) malların paketlerinde bazı değişiklikler yapmak durumunda kalmaktadır. Örneğin Hoffman La Roche v. Centrafarm ${ }^{45}$ davasında, Almanya ve İngiltere'de "Valium" markası ile piyasaya sürülen ilaç, Ingiltere'de 100 veya 500'lük tablet içeren paketlerde satılırken; paralel ithalatçı, bunları orijinal paketlerden çıkararak, Almanya'daki paketleme gereklerine uyarak 1000 'lik paketler halinde ambalajlamıștır.

Pfizer v. Eurimpharm ${ }^{46}$ davasında ise paralel ithalatçı, daha büyük paketlerde yeniden ambalajladığı "Vibramycin" marka antibiyotikleri, şeffaf biçimde paketlemiş ve kendi kimliğini de paket üzerinde açıklamıştır. Adalet Divanı benzer nitelikteki Centrafarm v. American Home Products ${ }^{47}$ davasında tüm bu sorunları aşağıdaki biçimde çözümlemiştir:

Marka, mal veya ambalaj üzerine konulan bir işarettir. Bu işaret satın alana, malın başka kaynaklı bir mal ile karışmasını önleme imkânı verdiğinden malın orijini konusunda bir garanti sağlamaktadır. Bu garantinin anlamı, pazarlamadan önce, marka sahibinin rızası dışında malın, orijinal şartlarını etkileyecek dïzeyde bir müdahaleye uğramadığıdır. Bu garantiyi etkileyecek değişiklikleri önleme hakkı, marka hakkının özïnï oluşturur. Bu nedenle üçüncü kişilerin (paralel ithalatçının), bunu yapmaya hakkı bulunmamaktadır. Fakat bir ürünün paketleme şartları, bir üye devletten diğerine farklılık gösteriyor ise ${ }^{48}$ paralel ithalatçı, marka hakkını ihlâl ediyor sayılmamak için şu üç noktaya dikkat etmek zorundadır:

- Paketleme, markalı malın orijinal şartlarını bozmayacak biçimde olmalıdır.

- Marka sahibi, yeniden paketlenmiș malların piyasaya sürüleceği konusunda uyarilmalidir.

- Yeni pakette, bu paketlemenin kim tarafindan yapıldığı belirtilmelidir.

Görüldüğü üzere Divan, marka sahibi, tüketici ve malların serbest dolaşımı konularında bir denge oluşturmaya çalıșmaktadır.

\section{Keurkoop v. Nancy Kean Gifts}

Divan bu konudaki ilk görüșünü bayan el çantalan ile ilgili Keurkoop v. Nancy Kean Gifts ${ }^{49}$ davasında belirtmiştir. Olayda Nancy, tasarım hakkı bir Amerikan

\footnotetext{
$45102 / 77$, ECR 1978, s. 1139.

46 1/81, ECR 1981, s. 2913.

$4^{-}$3/78, ECR 1978, s. 1923. Olayda paralel ithalatçı Centrafarm, aynı firmanın Ingiltere'de "Serenid", Hollanda'da "Selesta" markası altında piyasaya sürdüğỉ sakinleştirici ilaçlan İngiltere'den alarak Hollanda'ya ithal etmiş, bunu yaparken ilaçlar üzerine Hollanda'da kullanılan "Selesta" markasım koymuştur.

${ }^{48}$ Divan burada, üye devletin paketleme konusunda getirdiği şartların üye devletler arasındaki ticarete gizli bir engel oluşturmaması gerektirdiğini özellikle vurgulamaktadır. Bkz. 3/78, ECR 1978 , s. 1823 , para. 19.

49 144/81, ECR 1982, s. 2853.
} 
firmasına ait olan el çantalarını Tayvan'dan Hollanda'ya getirmiş ve Amerikan firmasından izin almadan, çantaların tasarımını kendi adına tescil ettirmiştir. Keurkoop'un, Tayvan'dan yaptığı ithalata Nancy, tescilli tasarım hakkına dayanarak karşı çıkmıştır.

Divan Nancy'nin başkasına ait bir çanta tasarımını kendi adına tescili açısından hakkın varliğ $\iota$ konusunu ulusal mevzuata bırakmış, ancak Nancy'nin, iptal edilmediği sürece tescile dayanan tasarım hakkının, Topluluk dışı bir ülkeden gelen aynı tasarımlı malın ithalatını önleme yetkisi verdiğini belirtmiştir.

Volvo v. Veng ${ }^{50}$ davasında ise Volvo 2000 serisinin tasarım tescili yapılmış ön çamurluk panelleri dava konusu olmuştur. Ingiltere'de kendisine Volvo arabaları ve yedek parçalarının satışı açısından inhisarî yetki verilen İngiliz Volvo, Volvo'nun izni olmadan anılan panelleri İngiltere'ye ithal ve imal eden Veng'i dava etmiştir. Divan, İngiltere'de de tescilli olan panellerin tasarım hakkının Volvo'ya, Veng'in üretim ve ithalatını önleme yetkisi verdiğini belirtmiştir.

Fikrî ve Sınaî Hakkın Tükenmesi ve Fikrî Haklar

- Deutsche Grammophon v. Metro ${ }^{5 !}$

Bir fikrî hak türü olan komșu haklardan plak yapımcılarının haklarını ilgilendiren davada Deutsche Grammophon (DG), plâkların Almanya'da toptan dağıtımını yapmış (nehaî tüketiciye satmamıştır) ve bir kısmını da Fransa'daki yavru şirketi Polydor'a göndermiştir. Fransa içindeki satışlarda DG plâkları nihaî tüketiciye satmak üzere Almanya'ya ithal etmiştir.

DG'nin, Almanya içindeki nihaî tüketiciye satma hakkını tüketmediğine ilişkin itirazı üzerine Divan:

"Hak sahibi, bir haşka üye devlette rızası ile piyasaya sürdüğ̈ ürünün, kendi ülkesine ithalini, nihâ tüketiciye dağıtımın yapmadığ için engellerse bundan,

- mallarin serbest dolaşım hükümleri ve

- ortak Pazar zarar görür"

şeklinde görüş bildirerek, hakkın tükendiğini vurgulamıştır.

\section{Fikrî ve Sınâ̂ Haklar Konusunda Vaz'edilen İkincil Mevzuat}

AT Antlaşması'nın 3. maddesinde vurgulanan politikalar çerçevesinde, ortak pazarın işlevselliğinin gerektirdiği hallerde üye devletler mevzuatını uyumlaştırma konumunda olan Topluluk; Adalet Divanı'nın yukarıda geliştirdiği ilkeleri de göstermek

\footnotetext{
${ }^{50} 238 / 87$, ECR 1989 , s. 6211 . Yedek parça niteliğinde olan ürünlerde, tasarım hakkının bu mutlak niteliği ile tüketicinin tamir ihtiyacı arasında denge arayışı 1993 yılında hazırlanan Tasarın Direktif ve Tüziiğünde, "Takir Amaçlı Kullanım" larda tasarım hakkı sahibinin mutlak yetki süresini 3 yıla indirmiştir. Ancak, AP, Ekim 1995 tarihinde bildirdiği birinci görüşmede süreyi kaldırarak, tamir amaçlı yedek parça imal ve ithalatında tasarım hakkı sahibine bir bedel ödenmesini önermiştir. Bkz. OJ.C 287, 30.101995, s. 157.
}

${ }^{51}$ 78/70, ECR 1971, s. 487. 
suretiyle, 1987 yılından itibaren fikrî ve sınaî hak alanında tüzük ve direktifler vaz'etmeye başlamıştır. Bunlar aşağıda, her iki konu başlığı için ayn ayrı ve ortak düzenlemeleri içerecek şekilde verilmektedir. Çalışması sürdürülen tasarılara da ayrıca yer verilmiştir.

\section{Fikrî Haklar Alantndaki Dïzenlemeler}

2001/84 sayılı Takip/Pay Hakkı Direktifi

(Directive on the Resale Right for the Benefit of the Author of an Original Work of Art)

Üye devletlerin 1 Ocak 2006 tarihine kadar iç hukuklarına aktarmaları gereken Direktif'in amacı; açık artırma salonları, galeriler gibi profesyonellerin düzenlediği Topluluk içindeki satış yerlerinde yeniden satışa tâbi tutulan sanat eseri sahipleri ve mirasçılarının, satış üzerinden belirli bir oranda pay almasını sağlayan kuralları uyumlaştırmaktadır.

Direktif'teki takip/pay hakkının kullanılabilmesi için satış bedelinin 3000 Euroyu aşması gerekmektedir. Direktif'e göre, hak sahibinin alacağı payın oranı, yine Direktif'te saptanan satış miktar aralıklarına göre belirlenmektedir ${ }^{52}$.

2001/29 sayılı Bilgi Toplumuna Uyum Direktifi

(Directive on the Harmonization of Certain Aspects of Copyright and Related Rights in the Information Society)

Direktif, fikrî hakların (eser üzerindeki hakların bağlantılı hakların) elektronik ortamda çoğaltılması, dağıtımı, umuma açıklanması, çoğaltmayı önleyici araç, program ve sistemlerin korunması konusunda uyumlaştırmayı amaçlamıştır. Direktif, servis sağlayıcıları ve telekomünikasyon kuruluşları açısından, onları koruyucu istisna hükümleri getirmektedir.

96/9 sayılı Veri Tabanlarının Korunması Direktifi

(Directive on the Legal Protection of Data Bases)

Direktifin en büyük özelliği, iki tip veri tabanı koruması öngörmesidir. Bunlardan ilki, orijinal nitelikli veri tabanları olup, koruma ilkeleri ve süresi açısından "eser" üzerindeki hakların korunması prensiplerine tâbi olacaklardır. Sui generis nitelikteki ikinci koruma ise orjinallik olmasa dahi, içeriğinin derlenmesi, kontrolü veya sunumu açısından önemli ölçüde aslî bir yatırım gerektiren veri tabanları ile ilgilidir. Direktif bunların 15 yıl korumadan yararlanacağını öngörmektedir.

93/98 sayılı Koruma Sürelerini Uyumlaştırma Direktifi

(Directive Harmonization the Term of Protection of Copyright and Certain Related Rights)

Direktif ile "eser" "üzerindeki haklar açısından koruma süresi, yaşam süresine ilâve olarak 70 yıl olarak belirlenirken; "bağlantılı" haklar için bu süre icra, tespit yayın tarihlerinden itibaren 50 yıl olarak uyumlaştırılmıştır. Bu Direktif daha sonra 2006/116 sayılı Direktif ile güncellenmiştir.

\footnotetext{
${ }^{52} 50.000$ Euroya kadar \%4, 50.000-200.000 arası \%3, 200.000-350.000 arası \%1 vb.
} 
93/83 sayılı Kablo İletimi ve Uydu Yayımlarda Fikrî Hakların Korunması Direktifi

(Directive on the Coordination of Certain Rules Concerning Copyright and Rights Related to Copyright Applicable to Satellite Broadcasting and Cable Transmission)

Direktif, 1989 yılında çıkanlan Sınırötesi Televizyon Direktifi'nin (Television Without Frontiers Directive) içermediği fikrî haklar konusunu düzenlemektedir. Bu düzenleme ile uydu yayınını yapan ișletmelerle, kablo iletimini sınırötesi şekilde sağlayan işletmelerin, fikrî ve sınaî hak sahiplerine karșı sorumlulukları ortak kurallara bağlanmıştır. Sınırötesi niteliği olan bu tür kablo iletimi ve uydu yayımlarında, sözleşmelerin kimlerle yapılacağı, telif ücretlerinin kimler tarafindan toplanacağı da ayrica Direktif' te yer verilen konular arasındadir.

92/100 sayılı Eser Üzerindeki Haklarla Bazı Bağlantılı Haklara İlişkin Ödünç ve Kiralama Yetkileri Direktifi

(Directive on Rental Right and Lending Right and on Certain Rights Related to Copyright in the Field of Intellectual Property)

$\mathrm{Bu}$ Direktif ile, yukarıda birinci ana başlık altında vurgulanan, fikrî hak sahiplerinin inhisarî yetkileri arasında yer alan; "kiralama" ve "ödünç verme" yetkilerine ilișkin kurallar uyumlaştırılmıştır. Bu Direktif daha sonra 2006/115 sayılı Direktif ile güncellenmiştir.

91/250 sayılı Bilgisayar Programlarını Korunmasi Direktifi

(Directive on the Legal Protection of Computer Programmes)

Fikrî haklar alanındaki ilk ikinci düzenleme özelliğini haiz olan Direktif; bilgisayar programlarının koruma şartları, hak sahibinin yetkileri, bu yetkilerin sınırlandırıldığı istisnalar ve koruma süresi konusunda hükümler içermektedir.

Sinaî Haklar Alanındaki Düzenlemeler

89/104 Marka Direktifi

(Directive to Approximate the Laws of Member States Relating to Trade Marks)

Mal ve hizmet markalarının; tescil, hükümsüzlük şartlan, hak sahibinin yetkileri ve bu yetkilere getirilen sınırlandırmalar, lisans sözleşmeleri, markanın kullanılması, kollektif, garanti ve sertifika markaları ile ilgili konularında üye devletler mevzuatını uyumlaştıran Direktif, bunun için üye devletlere 1991 yılı sonuna kadar süre tanımıştır.

40/94 sayılı Topluluk Marka Tüzügü

\section{(Council Regulation on the Community Trade Mark)}

AT, Topluluk düzeyinde kurduğu bir tescil bürosu aracılığı $\mathrm{ile}^{53}$ yine Topluluk düzeyinde bazı sınaî haklar yaratma politikası izlemektedir. Bu politikaya en uygun tasarruf türü kuşkusuz, "doğnıdan bağlayıcılığı" bulunan tüzüklerdir. Bu çerçevede yaratılan Topluluk markasının tescil ve başvuru şartları hak sahibinin yetkileri ve bu

\footnotetext{
${ }^{53}$ Merkezi İspanya'nın Alicante şehrinde bulunan ve 1995 yılında kurulan OHIM, bazı Topluluk düzeyinde olması vaz'edilen marka ve tasarımlar açısından bu işlevi yerine getirmektedir. OHIM (Office for Harmonisation in the Internal Market) tüzel kişiliği olan, hukukî, idarî ve malî özerkliğe sahip bir Topluluk kurumudur. Topluluk Markasının OHIM de tescili usulü ve ücretler gibi konularda da 'Tüzük' türünden ikincil düzenlemeler vazedilmişse de burada bu düzenlemelere değil sadece esasa ilşkin düzenlemelere yer verilmiştir. Ayrıntılı bilgi için bkz. Office for Harmonisation in the Internal Market web sayfasi, <http://oami.europa.eu/en/>
} 
yetkilere getirilen sınırlandırmalar, ulusal düzeydeki markalarla ilişkili, iptal ve hükümsüzlük nedenleri ve usulü Tüzük'te yer almıştır. Tescil ve itirazları inceleme makamı olarak görev yapan OHIM' in verdiği kararlar, İlk Derece Mahkemelerinde incelenmekte, temyiz üzerine ise Adalet Divanı temyiz makamı olarak hareket etmektedir.

\section{8/7 Tasarım Direktifi}

\section{(Directive on the Legal Protection of Desings)}

Tıpkı Marka Direktifi'nde olduğu gibi bu düzenleme de; iki ve üç boyutlu tasarımların koruma şartları, süresi, hak sahibinin yetkileri, bu yetkilerin sınırlandırılması, iptal ve hükümsüzlük konularında üye devletler mevzuatını uyumlaştırma amacıyla vaz'edilmiş ve üye devletlere bunun için 2001 yılı sonuna kadar süre tanımıştır.

\section{6/2002 Topluluk Tasarım Tüzüğü}

\section{(Regulation on Community Desings)}

Topluluk Marka Tüzüğü'nde olduğu gibi, Topluluk düzeyinde yaratılan tasarımların tescil, koruma şartları, süresi, hak sahibinin yetkileri, bunların sınırları, iptal ve hükümsüzlük konularını düzenleyen Tüzük, tescil makamı olarak OHIM'i tanımıştır.

Tüzük Topluluk Tasarımı ile ilgili olup, Tüzük hükümlerinin gözetilmesi gereken bazı davalar için, ulusal düzeyde bu konulara bakacak ilk ve son derece mahkemelerinin belirlenmesi ve bunların isimlerinin (6 Mart 2005 tarihine kadar) Komisyona bildirilmesi gerekmektedir. (Aynı yaklaşım Topluluk Markası için de benimsenmiştir.)

\section{8/44 Biyoteknolojik Buluşların Korunması Direktifi}

\section{(Directive on the Legal Protection of Biotechnological Inventions)}

Biyoteknolojik buluşlann korunması için, patent hukuku dışında aym bir hukuk yaratılmasına ihtiyaç bulunmamaktadır. Patent hukukunun temel ilkeleri bu alanda da geçerli olmakla birlikte; patentlenebilirlik şartlarını karşılamış "biyolojik materyalin" bazı özelliklerini dikkate alan hükümlere de ihtiyaç bulunmaktadır. Isște bu nedenle AT, üye devletlerin patent mevzuatını, bu buluşlar açısından uyumlaştırmayı amaçladığı 98/44 sayılı Direktifi vaz'etmiş ve üye devletlere uyum açısından 30.07.2000 tarihine kadar süre vermiştir.

\section{$87 / 54$ Yariletken Ürün Topografyalan Direktifi}

\section{(Directive on the Legal Protection of Topographies of Semiconductor Products)}

AT'nin, fikkrî ve sınaî haklar alanında ilik ikincil mevzuatı olan bu Direktif ile; yarı iletken ürün topografyalarının korunması, hak sahibinin yetkileri, koruma süresi gibi alanlarda üye devletler mevzuatının uyumlaştırılması hedeflenıniştir.

\section{0/94 Topluluk Yeni Bitki Çeşidi (Islahçı) Haklan Tüzüğü \\ (Council Regulation on Community Plant Variety Rights)}


AT bu konuda, sadece Tüzük vaz'etmek suretiyle Islahçı hakkını Topluluk düzeyinde tesis etmiş, tescil için ise Fransa'nın Angers kentinde faaliyet gösteren Topluluk Bitki Çeşitleri Ofisini ${ }^{5+}$ kurmuştur. Bu kurum da tıpkı OHIM gibi hukukî, malî ve idarî özerkliğe sahip bir kurum olarak oluşturulmuştur.

\section{Fikrî-Sinaî Haklar Hakkinda Ortak Dïzenlemeler ${ }^{55}$}

1388/2003 sayılı Fikrî ve Sınaî Haklan İhlâl Eden Mallara Karşı Gümrüklerde Eylem Tüzüğü

(Council Regulation Concerning Customs Action Against Goods Suspected of Intringing Certain Intellectual Property Rights and the Measures to be Taken Against Goods Found to have Infringed Such Rights)

Fikrî ve sınaî hakları ihlal eden taklit ve korsan malların gümrüklerde durdurulması, AT'nin 1986 yılından itibaren öncelikle konuları arasında yer almıştır. Bu konuda önce taklit markalarla ilgili $3842 / 86$ sayılı Tüzük, daha sonra ise bağlantılı haklar ve eser sahibinin haklarını ihlal eden korsan mallarla ilgili 3295/94 sayılı Tüzük çıkarılmıştır.

Nihayet 2003 yılında çıkarılan 1383/2003 sayılı Tüzük'le, kapsam; marka ve fikrî hakları ihlal eden taklit ve korsan malların dışında patent hakkı, yeni bitki çeşitleri ile ilgili ıslahçı hakkı, coğrafî işaret ve tasarım haklarını ihlâl eden malları da kapsayacak şekilde genişletilmiş ve önceki $3295 / 94$ sayılı Tüzük, 1 Temmuz 2004 tarihinden geçerli olmak üzere yürürlükten kaldırılmıştır.

Tüzük, bu tür hakları ihlâl eden mallarla ilgili kimlerin başvuru yapabileceğini, gümrük idaresinin yetki ve sorumluluklarını ve idare önündeki işlemlerde izlenecek usulü, ihlâl eden mallarla ilgili olarak alınacak tedbirleri, hak sahibi ve gümrük mercilerinin sorumluluklarını ayrıntılı bir şekilde düzenlemektedir.

\section{4/48 sayılı Fikrî ve Sınaî Hakların Etkin Korunması/Uygulanması Direktifi}

\section{(Directive on the Enforcement of Intellectual Property)}

Bundan önceki ikincil mevzuat ile fikrî ve sınaî hakların korunması ile ilgili "esasa" ilişkin hükümler uyumlaștırılmış iken, 2 Haziran 2004 tarihinde yayınlanan bu Direktif ile ilk kez fikrî ve sınaî hakların "uygulamada" etkin bir şekilde korunmasını sağlayıcı usule ilişkin tedbirler (ihtiyatî tedbirler) ve hukukî yaptırımlar uyumlaştırılmıştır.

AT, toplam 22 maddeden oluşan Direktif' in uygulanması için üye devletlere 29 Nisan 2006 tarihine kadar süre tanımıştır.

Direktif'te; fikrî haklar açısından bir hak sahipliği karinesi geliştirilmiş, hakkı ihlâl eden tarafın kontrolünde bulunan delillere mahkemelerin erişimi net bir şekilde

\footnotetext{
${ }^{54}$ The Community Plant Variety Office (CPVO)

${ }^{55}$ Bu bölümde hakkın korunmasını doğrudan gözetici ikincil mevzuat esas alınmıştır. Bu nedenle, doğrudan rekabetin korunmasını gözetip, fikrî ve smaî haklarla ilgili dolaylı hükümler içeren 772/2004, 240/96 gibi Komisyon Tüzüklerine burada yer verilmemiştir.
} 
vurgulanmış, ihtiyatî tedbirlerin alınma usulü, tedbir olarak nelerin talep edilebileceği, tedbir kararından sonra (üye devletler süre belirlememişse) esas hakkında davanın ne kadar sürede açılacağı, esas hakkında dava açılması halinde kararla birlikte ne tür tedbirlerin alınabileceği, tüm bu talepleri kimlerin isteyebileceği, tazminat ve masrafların nasıl hesaplanacağı, mahkeme kararının duyurulması ayrıntılı biçimde düzenlenmiş, uygun cezaî yaptırımların vaz'edilmesi konusunun üye devletlerin yetkisinde olduğu vurgulanmıştır.

\section{Fikrî ve Sinaî Haklar Konusundaki Tasarılar}

Topluluk Patent Tïzï̈̆̈̈ Tasarısi ${ }^{56}$

\section{(Proposal for a Council Regulation on the Community Patent)}

Topluluk düzeyinde bir patent sistemi yaratma hususunda ilk adım 1975 yılında, Topluluk Patenti Lüksemburg Sözleşmesi ile atılmış, sonra bu sözleşme'ye 1989 yılında bir anlaşma ile bazı ilâveler yapılmıştır. Fakat bu Sözleşme sadece 7 üye devlet tarafından onaylandığından hiçbir zaman yürürlüğe girememiştir. Bu başarısızlığın nedenleri arasında; patentin tüm Topluluk dillerine çevrilme zorunluluğunun getirdiği yüksek tercüme masraflan ile "ulusal" yargıç tarafından verilecek hükümsüzlük kararının tüm Topluluk alanında sonuçlar yaratmasından duyulan endişeler bulunmaktadir.

İşte yeni Tasarı, bu endişelerden de hareketle, tasarruf türü olarak "tüzïk" esas alınmak suretiyle hazırlanmıştır. İkinci önemli özelliği, tasarı ile 1973 tarihli Avrupa Patent Sözleşmesi (Münih Sözleşmesi) arasında sağlanan bağlantıdır. (Topluluk da Münih Sözleşmesi'ne taraf olacak ve patent verme işlemleri Münih Ofisi tarafından gerçekleştirilecektir. Tüzük tasarısının hükümleri, patentin Münih Ofisi tarafından tahsisinden sonraki durumu düzenlemektedir. Tercüme, patent maliyeti ve bir "Topluluk Patent Mahkemesi" ${ }^{-5}$ yaratma konularında Lüksemburg Sözleşmesi'ne getirilen eleştiriler bu Tüzük tasarısında bertaraf edilmeye çalışılmıştır.

Tüzük tasarısı Mayıs 2004 tarihinde görüşülmek üzere Konsey'e gönderilmiştir. Tasartsi ${ }^{58}$

Bilgisayar (yazılım) Uygulamalı Buluş̧arın Patentle Korunmasına Iliş̧kin Direktif

(Proposal for a Directive on the Patentability of Computer-Implemented Inventions)

Önerinin ana fikri; bir bilgisayar ya da benzer bir teknik aparat üzerinde bir yazılım uygulaması ile yapılmış bir buluşun patent ile korunması ve bu konudaki üye devletler mevzuatının uyumlaştırılmasıdır.

\footnotetext{
${ }^{56}$ Bkz. COM (2002) 412 final, 01.08.2000, 2000/0177.

5- Komisyon bu düşïnceyle 23.12.2003 tarihinde, Kunucu Antlaşma'ya Nis değişikliği ile eklenen 225 a maddesi çerçevesinde bir Karar Önerisinde bulunmuştur. (Bkz. COM (2003)828 final) Bu öneri ile "Topluluk Patent Mahkemesi" isimli bir yargısal panel olușturulacaktır. Bu mahkemenin vermiş olduğı kararlara karşı ise taraflar, Ilk Derece Mahkemesine temyiz başvurusunda bulunabileceklerdir.

${ }^{58} \mathrm{Bkz}$. COM (2002) 92 final, 20.02.2002, 2002/0047.
} 
Bu konudaki anlayış, Avrupa Patent Sözleşmesi’nin 52/(2-c) ve (3). maddesi ile şekillenmiş bulunmaktadır. Madde, bilgisayar yazılımlarının, "bizatihi" yazılım olarak patentlenemeyeceklerini öngörmüştür. Uygulamada, yazılım bağlantılı buluşlar ve bunların patentle korunduğu bilinmektedir. Direktif tasarısı, bu konudaki tereddütleri ve uygulamadaki farklılıkları giderici şekilde hazırlanmıştır.

Konsey, 18 Mayıs 2004 tarihinde tasarı hakkında görüşünü oluşturmuş olup, metin Avrupa Parlamentosuna iletilmiștir.

Faydalı Modellerle İlgili Çalışmalur

Bu konuda Komisyon tarafından iki grup çalışma yürütülmektedir:

İlki, Komisyon'un 1997 yılında hazırlayıp 1999 yılında gözden geçirdiği Faydalı Modellerin Korunması Hakkında Direktif Tasarısı'dır ${ }^{59}$

Direktif tasarısı ile faydalı modellerin korunmasına ilişkin üye devletler mevzuatındaki farklılıkların giderilmesi ve böylece iç pazarın bundan olumsuz etkilenmesi önlenmeye çalışılmıştır.

İkinci çalışma, Komisyon'un 2001 yılında ilgili sektörde yaptığı bir kamu oyu araştırması sonucunda; bazı çevrelerin bu konuda bir Topluluk Tüzüğü hazırlanması ve tıpkı Topluluk Patenti gibi bir Topluluk Faydalı Modeli yaratılması taleplerine dayalı olarak sürdürülmektedir. Henüz bir tüzük önerisi taslağı hazırlanmamıştır.

\section{Sonuç}

Giriş bölümünde de vurgulandığı üzere, fikrî-sınaî mülkiyet hakları konusunda üye devletlerin mevzuatındaki farklılıklar; malların serbest dolaşımının engellenmediği, rekabet düzeninin bozulmadığı bir iç pazarın tam olarak tesisine engel oluşturma riskini beraberinde getirmiştir. Bu risk, Topluluk Kurucu Antlaşması'nın hedeflediği entegrasyon amacı için tehlike niteliğini taşımıştır.

Kurucu Antlaşma'da fikrî-sınaî hakları düzenleyen ayrıntılı hükümler olmaması nedeniyle, ikincil mevzuatın vaz'edilmediği dönemlerde bu tehlikeyi bertaraf etme sorumluluğunu Adalet Divanı üstlenmiş ve geliştirdiği ilkelerle, daha sonra yapılan ikincil düzenlemelere ışık tutmuştur.

Bugün, hazırlanmakta olan tasarılarla birlikte fikrî-sınaî haklar konusunda AT, oldukça zengin bir ikincil mevzuat listesine sahip durumdadır. Sözü edilen mevzuat; İç Pazar Ofisi (OHIM), Bitki Çeşitleri Ofisi gibi AT düzeyinde bir kurumsal yapılanma da geliştirmiş, hatta bu konuda özel bir mahkemenin (Topluluk Patent Mahkemesi) kurulması da hazırlanan tasarılarda önerilmiştir.

${ }^{59}$ Proposal for a Directive for the Protection of Utility Models, COM (1999) 309 final, 25 June 1999. 


\section{KISALTMALAR}

$\begin{array}{lll}\text { AB } & : \text { Avrupa Birliği } \\ \text { AT } & : \text { Avrupa Topluluğu } \\ \text { ATAUM } & : \text { Avrupa Toplulukları Araştırma ve Uygulama Merkezi } \\ \text { Bkz/bkz } & : \text { Bakını } \\ \text { CMLRev. } & : \text { Common Market Law Review } \\ \text { CPVO } & : \text { The Community Plant Variety Office } \\ \text { ECR } & : \text { European Court Reports } \\ \text { IIC } & : \text { The International Review of Industrial Property and Copyright } \\ \text { IP } & : \text { Intellectual and Industrial Property } \\ \text { OHIM } & : \text { Office for Harmonization in the Internal Market } \\ \text { OJ } & : \text { Official Journal } \\ \text { RG } & : \text { Resmî Gazete } \\ \text { s. } & : \text { Sayfa } \\ \text { TRIPs } & : \text { Trade Related Intellectual Properties } \\ \text { Vb } & : \text { Ve bunun gibi } \\ \text { WIPO } & : \text { World Intellectual Property Organization } \\ \text { WTO } & : \text { World Trade Organization }\end{array}$

